\title{
«Porque tiene hambre Canina, Que nunca se harta». Narraciones de la muerte en Cervantes.
}

\author{
Carla Perugini \\ Università degli Studi di Salerno
}

RESUMEN:

A pesar de ser destino común para todos los hombres, las modalidades del morir son infinitas. Las fórmulas estereotipadas de los testamentos, incluidos los de los familiares de Cervantes, ponen de manifiesto una actitud cristianamente resignada de los moribundos, sin aspavientos ni temores. La manera de morir de Alonso Quijano, ya no Don Quijote, es buena prueba de ello. Pero los personajes cervantinos no mueren todos de buena gana: hay quien cae bajo la mano de otro, quien se quita la vida por su propia voluntad, quien pone en escena una muerte de ficción, quien muere heroicamente en la batalla o para salvar vidas ajenas. A veces es la consecuencia mortal de una metáfora: morir de amor, de dolor, de vergüenza... Este trabajo intentará dar cuenta de todo eso.

\section{PALABRAS CLAVE:}

Cervantes, muertes de ficción, muertes de verdad, testamentos.

\begin{abstract}
:
Nonostante sia destino comune a tutti gli uomini, le modalità del morire sono infinite. Le formule stereotipate dei testamenti, compresi quelli dei parenti di Cervantes, mettono in evidenza un atteggiamento cristianamente rassegnato dei moribondi, senza manifestazioni di paura scomposte. La maniera di morire di Alonso Quijano, non più Don Quijote, ne è buona prova. Ma non tutti i personaggi cervantini muoiono di buon grado: c'è chi cade per mano altrui, chi si toglie la vita di sua volontà, chi mette in scena una morte teatrale, chi muore eroicamente in battaglia o per salvare altre vite. A volte è la conseguenza mortale di una metafora: morir d'amore, di dolore, di vergogna... Di tutto questo cercherà di dar conto questo lavoro.
\end{abstract}

\section{PAROLE CHIAVE:}

Cervantes, morti letterarie, morti reali, testamenti.

Dentro de las innumerables tentativas de definición de la especie humana, la que más icásticamente sintetiza su naturaleza y su destino es la de mortales: «Et moriemur. Moriremo tutti» (Ariès, 2019: 50). Saber, gracias a esta sinécdoque, de ser 
partícipes de una suerte común no comporta necesariamente ni solidaridad entre los humanos ni preocupación constante por el fin de la vida, aunque las modalidades con las que a lo largo del tiempo esas actitudes se han manifestado justifican sin duda una historia de la muerte, con todos sus avatares y diferencias entre épocas y naciones.

Apartir de los comienzos del siglo xx, una cantidad cada vez mayor de historiadores, sociólogos, antropólogos y estudiosos de arte, han producido obras innovadoras sobre los consecutivos cambios de mentalidades, rituales y representaciones iconográficas y literarias del punto final de toda existencia. A los pioneros trabajos de Émile Mâle y Johan Huizinga sucedieron las nuevas miradas sobre los procesos de larga duración de la escuela francesa de las Annales, los ensayos de Alberto Tenenti y los de Michel Vovelle, Philippe Ariès, Jacques Le Goff, Pierre Chaunu y Jacques Chiffoleau, con los que empezó también el estudio de los testamentos ${ }^{1}$. Entre los españoles recordaremos por lo menos a Fernando Martínez Gil, Ariel Guiance, Emilio Mitre Fernández, Julia Pavón Benito o F. J. Díez de Revenga, dentro de un progresivo interés por la materia, atestiguado por el creciente número de congresos y publicaciones.

La época más estudiada es seguramente el Medievo, por su compenetración tan profunda entre vida y muerte, cuyas manifestaciones más impresionantes fueron las artes moriendi y la dança de la muerte ${ }^{2}$. Si la doctrina cristiana favorecía una actitud resignada del moribundo y contenidas expresiones del luto por parte de sus deudos en vista de la verdadera vida que esperaba al creyente en el más allá (la muerte domada de la que habla Ariès), con el paso del tiempo se incrementaron las preocupaciones acerca del juicio divino individual, la fascinación por lo macabro, la podredumbre, la descomposición del cuerpo -ya preferentemente denominado cadáver-, y los funerales aparatosos (la muerte propia según Ariès). La atención por tumbas, capillas y cementerios, la presencia de un erotismo lúgubre y a veces violento, el gusto por espectáculos de sufrimientos y suplicios, testimonian el sucesivo interés por la muerte del otro (la muerte ajena en las categorías de Ariès), que ya no tiene nada de consolador sino que se presenta como un acto de ruptura, agresivo y cruel. Con el siglo xx, ya desaparecidos los eróticos fantasmas románticos, la muerte reemplaza al sexo como interdicto, se vuelve algo censurable y silenciado, confinado en los hospitales o en las residencias para viejos (la muerte vedada) ${ }^{3}$.

Al escribir estas palabras en nuestro periodo de pandemia, mientras por primera vez en su historia la humanidad participa universalmente de los mismos luctuosos eventos con idénticos modos y tiempos, nos damos cuenta de no poder ya regir

\footnotetext{
${ }^{1}$ Para un excelente resumen, véase Azpeitia Martín (2008).

${ }^{2}$ Véanse Tenenti (1951), Morreale (1991 y 1996), Infantes (1997) y González Zymla (2014).

3 Adriano Prosperi recuerda que el sociólogo inglés Geoffrey Gorer, en «The pornography of death» (1955), sostuvo la tesis «della morte "nascosta" nella moderna società industriale, del sostituirsi della morte al sesso come oggetto di non-discorso» (1982: 392). Véase también Ariès (2019: 73).
} 
"Porque tiene hambre canina, que nunca se harta". Narraciones de la muerte en Cervantes

las riendas de ese caballo desbocado en el que convertimos a nuestro planeta hiperexplotado. Quizás en qué categoría hasta ahora no clasificada los historiadores del futuro pondrán a nuestros contemporáneos, muertos sin consuelos y $\sin$ esperanza...

En la partida de ajedrez que juega la Muerte con el caballero (icono inolvidable de la película de Ingmar Bergman, El séptimo sello) el hombre es el que siempre está destinado a perder, pero, a pesar de todo, o bien se pone en juego, o bien resiste en lo posible, como nos recuerdan los dramáticos versos de Antonio Machado en $\mathrm{Del}$ camino. Soledades (1899-1907), xxxv:

Al borde del sendero un día nos sentamos.

Ya nuestra vida es tiempo, y nuestra sola cuita

son las desesperantes posturas que tomamos

para aguardar... Mas Ella no faltará a la cita.

No solamente los individuos en carne y hueso antes o después acaban su existencia, sino también los personajes de ficción, en las artes figurativas como en las literarias, en los relatos míticos como en las películas. Nos aficionamos a ellos como a amigos queridos y abogamos por un happy end que el autor puede conceder o negar, así como puede resucitar a sus criaturas en cuentos fantásticos o bien en continuaciones y sagas. En el caso del Don Quijote, por ejemplo, la muerte del protagonista es narrada sin demasiado dramatismo, y con la finalidad explícita de impedir que otros autores pudieran apropiárselo, a la zaga de Avellaneda. Y, sin embargo, no podemos dejar de entristecernos al contemplar «el final de esta relación afectiva con nuestros personajes y narradores, el hecho de que todo para aquí y que no habrá más. No habrá nada más de este querido y admirado personaje-amigo mucho más grande que la vida y la muerte, y así tendremos que despedirnos para siempre» (Hutchison, 2016: 126). Es la misma tristeza que sentimos al abandonar cualquier obra de arte (sobre todo literaria) que nos haya arrebatado con su maestría.

No es necesario recordar los innúmeros estudios dedicados a la muerte de su héroe epónimo dentro de la inabarcable bibliografía sobre el Quijote. Si parva licet, me aproximo a aquella corriente de la crítica que justifica la rapidez y casi la incongruencia del fallecimiento del personaje con la voluntad de substraerlo a otras plumas que no fuesen la del autor autorizado, para que esos «presuntuosos y malandrines historiadores no te descuelgan para profanarte» (Cervantes, 2004: 1105), eso a la luz de la «noción de que la obra maestra de Cervantes es, ante todo, una obra diseñada para hacernos reír» (Iffland, 2016: 132). 
En todo caso, yo no me detendré exclusivamente en la muerte de su criatura más famosa, sino que intentaré hacer una panorámica de las muchísimas otras que salpican su obra, desde los poemas a las novelas y al teatro. Así como no me hallo de acuerdo con la tesis de quien ve la muerte de don Quijote como el fin que lo espera desde el comienzo de la novela (Sáez, 2012: 105), también quiero confutar que sean «contadas ocasiones en las que aparece» (Peñalver, 2006: 104). Diría más bien que el tema de la muerte es omnipresente en la entera obra de Cervantes, a partir de sus tempranos ejercicios poéticos (cuatro composiciones por el fallecimiento en 1568 de la joven reina Isabel de Valois, incluidas en el volumen encargado a su maestro, López de Hoyos), hasta las últimas palabras de saludo a la vida que encabezan el Persiles, en la dedicatoria al conde de Lemos y en el prólogo al lector de 1616. Pero, si el tema es idéntico, bien diferente es la manera de expresarlo: muchos cambios han intervenido entre el convencional y retórico duelo por el alma de la soberana, con sus invocaciones escolásticas a figuras del Olimpo pagano o cristiano, y la amable, sincera, auténtica confesión de un hombre en vísperas de la muerte, en vilo entre la pena de lo que tiene que dejar y la esperanza de poder gozar de unos días más: allí trasluce todo el arco de su existencia y de su escritura ${ }^{4}$. Naturalmente no es lo mismo conmoverse por una muerte ajena o por la propia, pero creo que, sea en la producción juvenil, sea en la tardía, la fe y la ortodoxia del escritor, nunca renegadas, se enfrentan, con mayor o menor fortuna, con una visión laica que ensancha el espacio de la libertad de expresión y crea una autonomía en los comportamientos de los personajes distante de la conducta prevista por los cánones sociales y religiosos. Si los arrebatos de don Quijote contra el cortejo de sacerdotes con hachas acompañando a un muerto en la noche (I, XIX) o contra una procesión de disciplinantes detrás de una imagen de la Virgen (I, LII), sus reprimendas contra la estrechez de algunos eclesiásticos (II, XXXII) o contra la ley, increpada por forzar a una hilera de hombres encadenados a ir a las galeras, «porque me parece duro caso hacer esclavos a los que Dios y naturaleza hizo libres» (I, XXII) (2004: 207) o los frecuentes desencuentros con la Santa Hermandad, si todos estos extremos encuentran su plausibilidad en la locura del caballero, no se podría justificar de otra manera que como libre elección del proprio destino la voluntad de vivir sin un compañero, sin hacerse monja y sin ceder a los chantajes sentimentales de los enamorados, de algunas figuras femeninas

\footnotetext{
${ }^{4}$ Aunque conocidísimas, quiero recordar las palabras de la Dedicatoria: «Ayer me dieron la Extremaunción [...]. El tiempo es breve, las ansias crecen, las esperanzas menguan, y con todo esto, llevo la vida sobre el deseo que tengo de vivir [...]. Pero si está decretado que la haya de perder, cúmplase la voluntad de los cielos»; y del Prólogo: «Mi vida se va acabando, y al paso de las efemérides de mis pulsos, que, a más tardar, acabarán su carrera este domingo, acabaré yo la de mi vida [...]. ¡Adiós, gracias; adiós, donaires; adiós, regocijados amigos; que yo me voy muriendo, y deseando veros presto contentos en la otra vida!» (Cervantes, 1990: 45 y 48-49).
} 
"Porque tiene hambre canina, que nunca se harta". Narraciones de la muerte en Cervantes

de los libros cervantinos -Marcela en el Quijote, Gelasia en La Galatea, Preciosa en La gitanilla, Angélica en La casa de los celos, Arlaxa en el Gallardo español, Halima en Los baños de Argel-, y eso sin presumir en el escritor un feminismo ante litteram, ya que no faltan, a lo largo de su obra, frecuentes atisbos de una rancia concepción de la mujer. Sin embargo, entre los personajes femeninos y masculinos son prevalentemente esos últimos los que escogen el suicidio por amor (pudorosamente disfrazado como «desesperación»). Llorones y petulantes, secundados por amigos y parientes, hacen pasar por fría crueldad la voluntad femenina de elegir libremente cómo vivir y a quién amar. Solo Don Quijote toma la defensa de la mujer con un apasionado discurso: «Ella [Marcela] ha mostrado con claras y suficientes razones la poca o ninguna culpa que ha tenido en la muerte de Grisóstomo y cuán ajena vive de condescender con los deseos de ninguno de sus amantes» (2004, I, XIV: 128).

En plena época postridentina, la Iglesia y la sociedad condenaban como el peor pecado contra Dios el matarse, pero no veían ningún problema en quitar la vida y aplicar el tormento a heréticos, presuntas brujas o enemigos de diferente nacionalidad o religión. El perceptible proceso de independencia del pensamiento de Cervantes se deja entrever sobre todo en el Persiles, donde son notables los malabarismos del autor para hacer convivir los rituales parareligiosos, a menudo paganizantes, de muchos personajes de la novela con la doctrina católica ${ }^{5}$. En la novela se justifica, por ejemplo, un intento de suicidio por razones no literariamente sentimentales sino hondamente humanas. Narra, pues, Periandro cómo un marinero de su nave se arrojó de la gavia, quedando «suspenso de un cordel que traía anudado a la garganta» (II, XIII, 1990: 229). Salvado in extremis, el hombre explica su gesto («la causa de su desesperación») con el haber dejado en patria a su joven familia, sin sustento y sin noticias, para seguir el sueño de hacerse rico. Los argumentos que Periandro usa para dar ánimo al marinero, lejos de ser religiosos, son resueltamente racionales. En otro lugar, la caída de lo alto de una torre sin consecuencias para una mujer, echada por un esposo al parecer enloquecido, se explica no por milagro sino por razones físicas, «sirviéndole de campana y de alas sus mismos vestidos» (1990, III, XIV: 373). Así, otro episodio de salvación de algunos marineros en la ribera de Génova se refiere no como milagro sino como misterio, ya que «los milagros suceden fuera del orden de la naturaleza, y los misterios son aquellos que parecen milagros y no lo son, sino casos que acontecen raras veces» (II, II, 1990: 164).

Más que por milagros, Cervantes parecía fascinado sobre todo por brujas y nigromantes. Y esto no solamente en una novela bizantina como el Persiles, que prevé en sus cánones la presencia de aventuras imposibles y sobrehumanas, sino

\footnotetext{
${ }^{5}$ Esto ya se notaba en La Galatea. Un posible pensamiento heterodoxo del Persiles ha sido sugerido por parte de la crítica, como Américo Castro (1957 y 1966) y Mauricio Molho (1976).
} 
incluso en una tragedia como Numancia, donde Marquino, «hechicero numantino», evoca los espíritus malos de la región oscura para resucitar a un muerto (Segunda Jornada, 2005: 96-103). Aterrado por sus nefastas previsiones, se arroja en la misma sepultura ${ }^{6}$.

Brujas y hechiceras aparecen en las Novelas ejemplares (El licenciado Vidriera, La española inglesa, El coloquio de los perros) y, en cuanto a las comedias, encontramos a un espectro en La casa de los celos, a demonios y almas del Purgatorio en El rufián dichoso. Evidentemente, de manera tradicional, estas figuras tematizan la muerte, pero donde se la describe con más ahínco es en las obras que Cervantes ambientó entre turcos y árabes (herencia de las doloridas experiencias de su cautiverio), con un porcentaje de asesinatos, torturas y mutilaciones decididamente alto. En realidad, escenas de violencia, que a veces llegan a verdadero sadismo, no faltan nunca en sus páginas, aunque, por un renacentista sentido de la mesura y de la discreción, logra mantener en equilibrio clímax y anticlímax, de modo que escenas cómicas intervienen para mitigar momentos de furia verbal o golpes mortales. Don Quijote, durante sus vagabundeos en busca de aventuras pares a las leídas en los libros de caballería, termina a menudo creído muerto, apaleado, con costillas rotas, dientes perdidos y heridas faltas del alivio del bálsamo de Fierabrás. Como su dueño, el pacífico Rocinante se ve obligado a entrar en batallas de las que sale roto y despedazado, y el mismo Sancho, que solo ejerce de escudero andante para mejorar su estado, se ve perseguido por manteos, azotes, peligros de guerra y caídas en abismos, de los que se preocupa sobre todo de preservar a su querido rucio. A pesar de tantas ofensas corporales, los dos protagonistas y sus cabalgaduras salen airosos, sin más consecuencias físicas, a la manera de títeres de retablillos o de modernos cómics, lo que ha confortado la tesis de quien ve en el Quijote una obra carnavalesca a la que interpretar a la luz de las categorías bachtinianas ${ }^{7}$. Como escribe el crítico ruso, que mucho admiraba a Cervantes:

La seriedad es oficial y es autoritaria, y se asocia a la violencia, a las prohibiciones y a las restricciones. Esta seriedad infunde el miedo y la intimidación [...]. La risa, por el contrario, implica la superación del miedo. No impone ninguna prohibición. [...] La victoria sobre la muerte no es sólo su eliminación abstracta, sino también su destronamiento, su renovación y alegre transformación: el infierno estalla y se convierte en cornucopia (2003: 73-74).

\footnotetext{
${ }^{6}$ Toda Numancia puede leerse bajo el sello de la Muerte, que sin embargo será vencida por la Fama (a lo Petrarca), en vista de las futuras hazañas de los príncipes españoles, herederos de los heroicos numantinos (sin olvidar a las mujeres).

${ }^{7}$ Véanse Cros (1988), Iffland (1994), Redondo (1997), Macías (2005), Fernández (2010) y Schmidt (2010).
} 
"Porque tiene hambre canina, que nunca se harta". Narraciones de la muerte en Cervantes

Podríamos sintetizar la actitud de Cervantes hacia la muerte con la fórmula gravitas vs. vis comica, donde los dos términos se contraponen y concuerdan, así que el balance final de su manera de afrontar la literatura es el de una escritura sin parámetros fijos ni respeto por formas predeterminadas, que fluyen de una a otra, mientras los géneros se mezclan y los cánones se dejan moldear por la libertad y la invención. Piénsese, por ejemplo, en La Galatea: ¿qué íncipit más tradicional y previsible que una elegía amorosa, un paisaje veraniego, entre riberas, ganados y verdes prados? Et in Arcadia ego: la contradicción llega de repente ya que en esta escena bucólica irrumpe la muerte, traída por un pastor con un cuchillo en la mano que asesina a otro y huye, maldiciendo al traidor, al que hay que negar la sepultura. Prosigue la narración con un sinnúmero de personajes, repleta de homicidios cruentos, traiciones y venganzas, robos de doncellas, incursiones de turcos en territorios cristianos con relativas violencias y profanaciones; y todo eso mezclado con cantos de pastores enamorados, instrumentos tocados a la luz de la luna, murmureo de fuentes y gorjear de pájaros, mujeres en travesti y trueques de personas. En las postrimerías del libro, muchas páginas están dedicadas a la celebración, de rito pagano, de un admirado y llorado difunto, Meliso, disfraz del poeta y político Diego Hurtado de Mendoza, muerto en 1575. No renuncia Cervantes a recursos bucólicos de ascendencia clásica e italiana (La Arcadia de Sannazaro), hasta acudir a lo maravilloso inexplicable con la aparición de la ninfa Calíope, a la que se debe el largo encomio de los poetas españoles. En este cuadro tan literaturizado aparece como una simulación el obsequio a una cristianización del texto a través de términos (plegarias, sacrificio, alma, amén...) que bien pueden leerse en sentido ambivalente, y una postiza tentativa de comprender la visión de la Musa «con algunos lícitos y acomodados exorcismos» (1995: 558).

La narración de la muerte en Cervantes se desarrolla bajo diferentes aspectos, entre lo macabro, lo épico, lo cómico y lo teatralizado. De esta última especie hay muchos ejemplos en el Quijote, sea en la primera parte por equívocas lecturas que el caballero da de inocuos funerales o de retablos de marionetas, sea en la segunda parte por las elaboradas construcciones y las performances actorales orquestadas por los Duques para divertirse a expensas de su huésped. Don Quijote había asistido a la fingida muerte de Basilio para casarse con Quiteria durante las bodas de Camacho (I, XXI) y a los verdaderos funerales de Grisóstomo (I, XII), mientras solo Sancho (ya que su amo se había quedado dormido) había escuchado en la venta la lectura de la puesta en escena del engañoso suicidio de Camila en el Curioso impertinente (I, XXXIV), impostura a la que seguirán las auténticas muertes de los personajes de la novela. Uno de los episodios más significativos de los híbridos cruces que el protagonista opera entre realidad y ficción es el de la carreta de los representantes, 
entre los cuales sobresale una Muerte no con calavera sino con rostro humano, junto a otras figuras espantosas, como un demonio y un moharracho vestido de bojiganga, que provocará el desastroso desenlace (II, XI). En otro caso, una figura de muerte toda vestida de ropa negra, con un velo que cubre una faz descarnada y fea, se revela ser Merlín, quien, con su profecía, impone la pena de los tres mil y trescientos azogues en las posaderas de Sancho para que se desencante Dulcinea (II, XXXV).

A pesar de su asombrosa aparición, sobre un carro tirado por seis mulas, entre luces, oro y plata, el presunto mago artúrico se revela bastante razonable respecto a la resistencia que opone Sancho a fustigarse, acabando los dos con un pacto de gentlemen's agreement ${ }^{8}$. Y vuelve a aparecer como causa de los encantamientos de los habitadores de la cueva de Montesinos (II, XXIII), aunque el venerable anciano desmienta la fama del mago de ser hijo del diablo?: «lo que yo creo es que no fue hijo del diablo, sino que supo, como dicen, un punto más que el diablo» (2004: 725). Esta aventura de don Quijote, una de las más llevadas y traídas por lo que al conflicto entre verosimilitud y mentira se refiere, es un extraordinario ejemplo de la habilidad cervantina de hacer coexistir gravitas y vis comica, ya que una narración presuntamente lúgubre por tema y personajes se vuelve del revés, merced a un trato irónico que desnuda a magos, damas y caballeros de sus nobles ascendencias legendarias y literarias, revelando toda la miseria y la ridiculez de unos cuerpos momificados y malolientes. La repetitividad de rituales aparentemente severos (la procesión de las doncellas que acompañan a la señora Belerma, los suspiros de Durandarte, la respuesta de su primo Montesinos, la ostensión del corazón seco y amojamado, sobre el que las mujeres cantan endechas ${ }^{10}$ cuatro días en la semana) se mezcla con la presencia de unos elementos totalmente incongruentes con el aparente registro alto de la escena, rebajándolo de manera tan imprevista cuanto irreversible. Entra sin más ese vocabulario familiar y grosero, esa parodia de los héroes, esa anulación de las fronteras entre actores y espectadores, que Bachtín atribuye al espectáculo carnavalesco, y que en este capítulo del libro permite que se revele que la Dama tenía ojeras «por estar con el mal mensil ordinario en las mujeres» o que Montesinos tuvo que lavarse las manos sucias por hurgar en las entrañas del primo y

\footnotetext{
${ }^{8}$ Otra vez aparece Merlín, en figura de espectro, con sus profecías en la comedia La casa de los celos.

${ }^{9}$ Así es según la leyenda narrada por Geoffrey de Monmouth en la Historia Regum Britanniae.

${ }^{10}$ La presencia de las endechaderas se repite en Cervantes, como elemento luctuoso muy escenográfico ya que las mujeres, amén de llenar el aire de sus lamentos y gritos, se afeaban el rostro, se arrancaban los cabellos y se vestían con ropa pobre y basta: así el ama y la sobrina a la tercera salida de su señor (Quijote, II, VII), Claudia Jerónima después de matar por infundados celos a don Vicente (II, LX) o Ruperta llevando consigo la cabeza de su esposo y meditando venganza en el Persiles (III, XVI). Era costumbre antigua, secundada hasta por señoras aristocráticas o de la familia real: véanse Vitale (2007) y Niccoli (2007).
} 
"Porque tiene hambre canina, que nunca se harta". Narraciones de la muerte en Cervantes

echar un poco de sal en su corazón para que no oliese mal. Por otra parte, el lenguaje de este muerto vivo no es propiamente (como no dejará de notar Sancho) el que nos esperaríamos de un noble caballero ${ }^{11}$, como tampoco esperaríamos encontrar entre tan noble compañía a una de las labradoras compañeras de la encantada Dulcinea, pidiéndole a don Quijote un préstamo de media docena de reales, que él solo puede satisfacer con cuatro.

Otra cueva habrá más tarde, en la que se precipitará Sancho con su rucio volviendo de la ínsula Barataria, pero aquí también la tragedia de la muerte se evitará, ya que los dos caen sin mayores consecuencias y terminarán encontrando la salida para volver al castillo de los Duques (II, LV).

Es justamente Sancho, pese a su (aparente) simplicidad, el personaje al que Cervantes confía la mayoría de las reflexiones sobre la muerte, reflexiones que no son derivadas solo de aquellos refranes que caracterizan su lenguaje ${ }^{12}$, sino de razonamientos que a veces dejan maravillado al mismo don Quijote. Sin duda, él hace de portavoz de una sabiduría popular que englobaba el fallecimiento como un tránsito natural hacia un más allá democráticamente común a todos los hombres. $\mathrm{Al}$ saber que tenía que morir, el hombre aceptaba su destino sin demasiada sorpresa o aspavientos. Se echaba en la cama consciente de que el fin sobrevendría dentro de pocos días, ya que a las enfermedades de un tiempo raramente se sobrevivía. Era la ocasión para hacer un balance de la propia vida, recibir los sacramentos y dictar sus voluntades con el testamento. Todos, ricos y pobres, letrados e ignorantes, se servían de las mismas fórmulas, que podemos leer gracias a muchas investigaciones de $\operatorname{archivos}^{13}$, que empezaban encomendándose a Dios, a la Virgen y a los Santos de su devoción. Inmediatamente después el otorgante reconocía la fugacidad de la vida humana: «Porque nenguna persona en carne puesta de la muert corporal no pueda escapar, et non sia a cada uno mas cierta cosa que la muert ni mas incierta que la ora de aquella» (Falcón y García, 2007: 333), aseguraba ser sano de mente, confirmaba su identidad delante de los testigos, revocaba testamentos anteriores, encargaba a los herederos saldar sus deudas, dejaba lo que les correspondía al cónyuge así como a los hijos y a los criados de la casa, disponía porcentajes notables de sus bienes en mandas para la Iglesia, monasterios, capillas y cofradías, y una cantidad increíble de misas para la propia alma, ya que, a partir de la invención del Purgatorio (siglos XIIXIII) se introdujo una contabilidad del más allá, que reglamentaba minuciosamente

\footnotetext{
${ }^{11}$ «Digo, paciencia y barajar» (2004: 727), que es una expresión de los jugadores de naipes y que Cervantes volvió a usar en el final de la comedia Laberinto de amor.

${ }^{12}$ Mucho más en la segunda parte que en la primera, en realidad.

${ }^{13}$ Es muy amplia la bibliografía sobre los testamentos. Me limito a unos títulos que me han sido útiles para este trabajo: Coria (1982), Casey (2001), Aurell (2002), Pavón (2004), Andrade (2005), García (2008), Rutherford (2008), Sáez (2012), Barco (2018) y Cadaveira (2018).
} 
la relación entre número de misas en el mundo y duración de la pena en el más allá (Chiffoleau, 1980; Le Goff, 1981).

Eso es más o menos lo que dicta don Quijote en su testamento, aunque sin demasiadas referencias a la doctrina cristiana. Cervantes solo nos dice que se confesó con el cura y que delante del escribano ordenó su alma «con todas aquellas circunstancias cristianas que se requieren» (II, LXXIV, 2004: 1102). Las circunstancias de su fin son las auspiciadas por el buen cristiano ya que, a partir del concilio de Trento, el ars bene moriendi, sobre la que escribe el cardenal Bellarmino, depende de cómo se ha vivido: «De primo praecepto Arte bene moriendi, bene vivat» (González, 2005: 301) ${ }^{14}$. Pero, durante una conversación que tuvo con un mozo que quería ir a la guerra, el caballero afirma, exaltando la milicia sobre las letras, que si la muerte es buena, «el mejor de todos es morir». Acto seguido recuerda una anécdota de Julio César: al interrogarle sobre cuál sería la mejor muerte, «respondió que la impensada, la de repente y no prevista; y aunque respondió como gentil y ajeno del conocimiento del verdadero Dios, con todo eso dijo bien». Y añade: «Todo es morir, y acabóse la obra, y según Terencio más bien parece el soldado muerto en la batalla que vivo y salvo en la huida» (2004, II, XXIV: 739) ${ }^{15}$. Cervantes se equivoca: no es Terencio la fuente de la cita, sino Tácito, que así escribe a propósito de los germanos: «Iam vero infame in omnem vitam ac probrosum superstitem principi suo ex acie recessisse. Illum defendere, tueri, sua quoque fortia facta gloriae eius adsignare praecipuum sacramentum est. Principes pro victoria pugnant, comites pro principe» (Germania, 14). No parece muy ortodoxo este pensamiento de don Quijote, si bien es cierto que, como escribe E. Mitre Fernández, en esta época «la muerte imprevista (la subitanea mors) sin ninguna preparación [...] puede llegar a constituir toda una obsesión para el cristiano»(2003-2004). Se empeñaban en aterrorizarlo las preparaciones a la muerte de los predicadores y las pinturas que de la Dança de la muerte se veían en los muros de las iglesias y de los cementerios, o bien las xilografías de la alemana Die kampf um die seele, que prometía una macabra batalla por el alma en el momento final, con la cama del agonizante disputada por las bandas angélicas y las demoníacas. Una de esas imágenes (la 3a, Versuchung durch Ungeduld, la tentación por impaciencia) hace referencia a la excitación de los circunstantes que esperan que el moribundo se vaya pronto para recibir su herencia. Este, airado, tira una coz contra uno de ellos ${ }^{16}$, lo que nos hace pensar en la consideración de Cervantes a propósito del testamento de don Quijote: «Andaba

\footnotetext{
${ }^{14}$ Se pueden leer varios testamentos de deudos y personas relacionadas con Miguel de Cervantes en Sliwa (2005).

15 «[...] el soldado más bien parece muerto en la batalla que libre en la fuga» (2004, II, Prólogo al lector: 543).

${ }^{16}$ Se puede ver en http://userpage.fu-berlin.de/ aeimhof/seelefr.htm (última consulta: 3/12/2020).
} 
"Porque tiene hambre canina, que nunca se harta". Narraciones de la muerte en Cervantes

la casa alborotada, pero, con todo, comía la sobrina, brindaba el ama y se regocijaba Sancho Panza, que esto del heredar algo borra o templa en el heredero la memoria de la pena que es razón que deje el muerto» (2004, II, LXXIV: 1104) ${ }^{17}$.

Volviendo a las consideraciones de Sancho acerca de la muerte, mientras en el capítulo VII de la segunda parte ensarta una serie de refranes más o menos coherentes dirigidos a persuadir a su dueño a que le establezca un salario pagado mensualmente, durante las bodas de Camacho (II, XX) enumera otra retahíla sobre el tener y el no tener, y es reprendido por don Quijote, que espera verlo mudo antes que muera. Esto da a Sancho la ocasión para exhibirse en otras variaciones sobre el tema por las cuales su amo le tilda de «buen predicador»:

Tiene esta señora más de poder que de melindre; no es nada asquerosa: de todo come y a todo hace, y de toda suerte de gentes, edades y preeminencias hinche sus alforjas. No es segador que duerme las siestas, que a todas horas siega, y corta así la seca como la verde yerba; y no parece que masca, sino que engulle y traga cuanto se le pone delante, porque tiene hambre canina, que nunca se harta; y aunque no tiene barriga, da a entender que está hidrópica y sedienta de beber solas las vidas de cuantos viven, como quien se bebe un jarro de agua fría. (2004, II, XX: 706)

La insistencia sobre una Muerte representada, más que con la hoz o la flecha de la iconografía más trivial, con dientes, boca y barriga, una muerte perpetuamente hambrienta como un perro, remite a unos versos de la Dança de la muerte, cuando habla el Patriarca: «iOh omne mesquino que en grand ceguedad / andove en el mundo, non parando mientes / cómo la muerte con sus duros dientes / roba a todo omne, de cualquier edad» (Morreale, 1991: 33), y a la figuración del Tiempo así como la encontramos en Ovidio, Metamorfoseon, liber XV: «tempus edax rerum, tuque, invidiosa vetustas, / omnia destruitis vitiataque dentibus aevi / paulatim lenta consumitis omnia morte!» (vv. 234-236). Como sugiere E. Panowski, en efecto, «Il Tempo, appropriatosi delle qualità del mortale, cannibale Saturno che brandisce il falcetto, è entrato in relazione sempre più stretta con la Morte [...] Il tempo a sua volta poteva raffigurarsi come ministro della Morte, che egli provvede di vittime, o come demone dai denti di ferro ritto in mezzo alle rovine» (cursivas mías) (1975: 112).

No será casual la imagen de una muerte que nunca se harta en boca de Panza (nomen omen), imagen que podría también haber sido suscitada por las representaciones del

\footnotetext{
${ }^{17}$ En la Novela del celoso extremeño, el viejo Carrizales se comporta en su último día muy noblemente, dejando como herederos a la mujer infiel y a todos los de la casa: «Quedaron los padres de Leonora tristísimos, aunque se consolaron con lo que su yerno les había dejado y mandado por su testamento. Las criadas se consolaron con lo mismo, y las esclavas y esclavo con la libertad; y la malvada de la dueña, pobre y defraudada de todos sus malos pensamientos» (2003, II: 135).
} 
transi, es decir, del difunto en el ataúd, en descomposición, con el vientre abierto, como se puede ver en el Llibre vermell de Montserrat (f. XXVIIr) ${ }^{18}$ del siglo XIV o en las pinturas de la Sala Capitular del Convento de San Francisco de Morella (Comunidad Valenciana) del siglo XIII.

Sancho, como hombre del pueblo, educado en el temor y la credulidad hacia las manifestaciones del más allá, a lo largo de sus aventuras reacciona con miedo a las apariciones de la descarnada, que no será detenida ni por ruegos ni por fuerza, «según es pública voz y fama, y según nos los dicen por esos púlpitos» (II, VII, 2004: 596). Por otra parte, durante fiestas o festejos, tanto el pueblo por las calles cuanto los nobles en sus residencias, podían rebelarse a la obediencia y al miedo a través de personajes disfrazados de muerte o demonios, con máscaras feas y espantosas, cuya patente falsedad demostraba «cómo lo macabro podía trivializarse y devenir entretenimiento» (Falcón y García, 2007: 329). Es lo que sucede en el palacio de los Duques, que llegan a tales extremos que el ingenuo Sancho más veces los pone en duda, mientras que su amo solo ve en ello ocasiones de nuevas hazañas. En cambio, pese a las largas conversaciones tenidas con el escudero del Caballero del Bosque (o de los Espejos) y haber compartido con él amigablemente comidas y bebidas, Sancho "comenzó a herir de pie y de mano, como niño con alferecía» (II, XIV) cuando, al salir la luz del día, descubre la descomunal nariz de «aquel vestiglo», cuya grandeza y color no habrían podido engañar al mismo niño sobre su falsedad. En todo caso, aquí como en otros lugares, la carencia de verosimilitud aumenta la comicidad de la escritura, para diversión de nosotros los lectores.

Mientras las descripciones de la Muerte por parte de Sancho salen ex abundantia cordis, enfatizando y personalizando los tópicos, las que hace don Quijote reflejan imágenes muy divulgadas a través del discurso literario, filosófico y teológico. A fuentes reconocibles se debe la comparación de la vida con una comedia en la que cada uno interpreta un papel, que tiene que dejar cuando «a todos les quita la muerte las ropas que los diferenciaban, y quedan iguales en la sepultura» (II, XII), tanto que su compañero replica:

-Brava comparación -dijo Sancho-, aunque no tan nueva, que yo no la haya oído muchas y diversas veces, como aquella del juego del ajedrez, que mientras dura el juego cada pieza tiene su particular oficio, y en acabándose el juego todas se mezclan, juntan y barajan, y dan con ellas en una bolsa, que es como dar con la vida en la sepultura. (2004, II, XII: 631-632)

\footnotetext{
${ }^{18}$ La reproducción se halla en www.cervantesvirtual.com (última consulta: 3/12/2020).
} 
"Porque tiene hambre canina, que nunca se harta". Narraciones de la muerte en Cervantes

Tanta elegancia le viene a Sancho directamente, como él mismo admite, de la frecuentación con don Quijote, aunque lo explica de manera no propiamente elegante: «Quiero decir que la conversación de vuestra merced ha sido el estiércol que sobre la estéril tierra de mi seco ingenio ha caído». Nuevamente se complace don Quijote de la discreción de su escudero por la comparación que este hace de la muerte con un término de raigambre virgiliana (Eneida, VI, 522): «Sola una cosa tiene mala el sueño, según he oído decir, y es que se parece a la muerte, pues de un dormido a un muerto hay muy poca diferencia» (2004, II, LXVIII: 1065). En una obra famosa, que Cervantes pudo conocer, como fue la Iconologia de Cesare Ripa, cuya princeps se publicó en Roma en 1593, se describe la Muerte como una mujer con los ojos cerrados, por la falta de lumbre, añadiendo: «Overo perché come il sonno è una breve morte, così la morte è un lungo sonno, e nelle sacre lettere spesso si prende per la Morte il sonno medesimo» (2012: 401).

Además de a sus lecturas de intelectual, las representaciones más cruentas que Cervantes hace de la muerte se deben a sus vivencias como soldado y como prisionero. Por ser hombre acostumbrado a batallas y estragos, la presencia de decenas de cadáveres es narrada con pinceladas rápidas, sin particular emoción, incluso cuando de particulares macabros se habla, como en el caso de los árboles llenos de ahorcados en el bosque cerca de Barcelona, o cuando el bandolero Roque Guinart castiga a uno de los suyos abriéndole la cabeza en dos partes (II, LX). En cambio se percibe una auténtica conmoción al referir muertes particulares, sobre todo de jefes de milicias, o bien los crueles tormentos que los turcos infligían a sus cautivos cristianos. En su discurso de las armas y las letras don Quijote ya había subrayado con énfasis los peligros que acompañan la vida del soldado, continuamente amenazado por «tantos ministros de la muerte» (2004, I, XXXVIII: 397), pero es sobre todo en la historia del cautivo que llega con la hermosa mora a la venta de Maritornes donde se reflejan, con elaboraciones novelescas, episodios realmente vividos por el escritor, que no pasa por alto nombres de personajes históricos y hazañas heroicas y malogradas. Así, entre solapadas alusiones a errores cometidos en la conducción de la guerra, se narran algunas conmovedoras muertes, como la del comandante genovés Pagán de Oria (Pagano Doria), que había participado en la conquista de Túnez con Juan de Austria y luego había sido enviado a defender el fuerte de La Goleta. Delante del desbordante ejército del sultán Selim que lo asedió por tres meses, sin esperanzas de salvación, Doria se entregó a cuatro moros de su confianza para que le llevaran a un portezuelo tenido por los genoveses en Tabarca, pero estos alevosamente le mataron y le cortaron la cabeza, llevándola al general de la armada turquesca. Sin embargo, como "“aunque la traición aplace, el traidor se aborrece" se dice que mandó el general ahorcar a los que le trujeron el presente, porque no se le habían 
traído vivo» (2004: 406). Cervantes alaba «la suma liberalidad» de Doria con su hermano Juan Andrea ${ }^{19}$ así como lamenta la muerte de tantas «personas de cuenta» y el haber muerto de pesar el general de La Goleta, don Pedro Puertocarrero, camino de Constantinopla, donde también fue llevado como prisionero el famoso ingeniero italiano Gabrio Serbelloni ${ }^{20}$. Los cautivos cristianos, sea en las galeras sea en los baños de Argel, eran cruelmente vejados por sus guardianes, encadenados, entre hambre y desnudez, esperando un rescate, pero lo peor eran las sacas imprevistas de prisioneros ordenadas por el poderoso renegado Azán Agá, de origen veneciano, el cual, por puro sadismo, «cada día ahorcaba el suyo, empalaba a éste, desorejaba aquél, y esto, por tan poca ocasión, y tan sin ella, que los turcos conocían que lo hacía no más de por hacerlo y por ser natural condición suya ser homicida de todo el género humano» (2004, I, LX: 410). Durante su cautiverio, en 1577, Cervantes logró enviar una carta al influyente secretario de Felipe II, Mateo Vázquez de Leca, a través de un amigo común, Antonio de Toledo. En el poema contenido en ella (que aparece también con variantes en Los tratos de Argel) lamenta su condición y la de los otros prisioneros, invocando la ayuda de las fuerzas españolas, ya que «Vida es esta, Sr., do estoy muriendo, / entre bárbara gente descreída, / la mal lograda juventud perdiendo», y evocando la sangrienta y gloriosa batalla de Lepanto en la que participó en 1571 (Gonzalo, 2007: 204):

La muerte ayrada, con su furia insana, aquí y allí con priessa discurriendo, mostrándose a quien tarda, a quien temprana.

El son confuso el espantable estruendo, los gestos de los tristes miserables que entre el fuego y el agua iuan muriendo.

Los profundos sospiros lamentables que los heridos pechos despedían maldiziendo sus hados detestables.

Pero Felipe prefirió invertir sus tropas y su dinero en las campañas de Flandes, dejando a la caridad de los frailes mercedarios y trinitarios los onerosos rescates de los prisioneros.

El cautivo del Quijote recuerda las muertes heroicas de los soldados en Lepanto («más ventura tuvieron los cristianos que allí murieron que los que vivos y vencedores quedaron»), las de los valerosos (para los Flamencos) condes de

\footnotetext{
${ }^{19}$ En realidad Pagano murió sin herederos, por lo que Giovanni Andrea recibió en 1575 los feudos de su hermano por el emperador Maximiliano II: véase Bernabò (2002: 14).

${ }^{20}$ Por los italianos implicados en los hechos de Túnez me permito remitir a mi estudio: Perugini (2017).
} 
"Porque tiene hambre canina, que nunca se harta". Narraciones de la muerte en Cervantes

Eguemón y de Hornos, los millares de turcos matados por los sitiados de La Goleta o el fin espeluznante del cruel hijo de Barbarroja por mano de los cautivos de su galera La Presa:

soltaron todos a un tiempo los remos y asieron de su capitán, que estaba sobre el estanterol gritando que bogasen apriesa, y pasándole de banco en banco, de popa a proa, le dieron bocados, que a poco más que pasó del árbol ya había pasado su ánima al infierno: tal era, como he dicho, la crueldad con que los trataba y el odio que ellos le tenían. (2004, I, XXXIX: 402 y 404)

El cautiverio viene recordado por Cervantes también en otro poema, el que empieza con «Bate, fama veloz las prestas alas» (2016: 232) y en muchos lugares de su teatro. Al lado de todas esas muertes por delitos, guerras o suicidios, su escritura cumple un nuevo compromiso con la muerte como obra de lenguaje, consecuencia de metáforas. Así, si don Pedro Puertocarrero, general de La Goleta, muere de pesar, y Ricaredo en La española inglesa casi pierde su vida por el dolor, porque estaba enamorado de Isabela, el impertinente Anselmo entiende que se le va acabando la vida por la vergüenza de haberlo perdido todo:

Viéndose, pues, solo, comenzó a cargar tanto la imaginación de su desventura, que claramente conoció que se le iba acabando la vida, y, así, ordenó de dejar noticia de la causa de su extraña muerte; y comenzando a escribir, antes que acabase de poner todo lo que quería, le faltó el aliento y dejó la vida en las manos del dolor que le causó su curiosidad impertinente. (2004, I, XXXV: 373)

Asimismo Camila, al conocer la muerte en batalla de Lotario y la de su esposo, «acabó en breves días la vida a las rigurosas manos de tristezas y melancolías» (I, XXXV, 2004: 374). Igualmente prevén sus muertes de dolor la hermosa Galatea, prometida en esposa a un desconocido, y su enamorado pastor Elicio (1995: 507 y 510).

Pero la muerte más significativa en este sentido es precisamente la del héroe epónimo, ya que la causa de su enfermedad mortal otra no es que la melancolía, como diagnostica Sancho en su célebre lamento: «la mayor locura que puede hacer un hombre en esta vida es dejarse morir sin más ni más, sin que nadie le mate ni otras manos le acaben que las de la melancolía» (2004, II, LXXIV: 1102). Al volver definitivamente a su aldea, don Quijote había pronosticado algo funesto por unos agüeros que Sancho había desmentido, recordándole cómo en otros días su amo le había recomendado no creer en ellos. 
En efecto, camino para Zaragoza, a la que nunca llegarán, el caballero había revelado a Sancho que los que el vulgo llama comúnmente agüeros «no se fundan sobre natural razón alguna» (2004, II, LVIII: 988). En todo caso, una calentura le tuvo seis días en la cama. Al decirle el médico que pensase en su alma, ya que el cuerpo corría peligro por causa de melancolías y desabrimientos, don Quijote cayó en un sueño de seis horas, al despertarse del cual declaró haber recuperado la cordura. En otras ocasiones el hidalgo con un largo sueño se había recuperado de apaleamientos y heridas; ahora, a lo que parece, el sueño sirvió para salvarle de la locura. En su época, y por mucho tiempo antes y después, la melancolía fue considerada una enfermedad, con sus síntomas y terapias. Alonso Freylas, médico de cámara del arzobispo de Toledo e Inquisidor General don Bernardo de Sandoval y Rojas ${ }^{21}$, escribió un tratado titulado Si los melancólicos pueden saber lo que está por venir o adevinar el sucesso bueno o malo de lo futuro, con la fuerça de su ingenio, o soñando (1606), en el que, aún negando que se pueda conocer el futuro, afirmaba que con los melancólicos es posible: «Eso ocurre, por ejemplo, cuando en las enfermedades se hace lábil la unión de alma y cuerpo, pero también durante el sueño, tanto que muchos, soñando, han encontrado peregrinas soluciones a numerosos dilemas, compuesto sonoros versos y hablado con elegancia en latín» (Gambin, 2008: 219).

También para el caballero de la triste figura el sueño, tan parecido a la muerte, ha abierto las puertas de la sabiduría, y para su creador, que seguirá la suerte de su criatura poco tiempo después, ha hallado una peregrina solución a un importante problema: cómo hacer morir a Alonso Quijano para que siguiera viviendo don Quijote. Vale.

\section{Bibliografía}

Andrade Cernadas, José M., «Los testamentos como reflejo de los cambios de actitud ante la muerte en la Galicia del siglo XIV», Sémata. Ciencias Sociais e Humanidades, n. $^{\circ}$ 17, 2005, págs. 97-114.

Ariès, Philippe, Storia della morte in Occidente, Milán, BUR Rizzoli, 9. ${ }^{a}$ ed., 2019. Aurell Cardona, Jaume, «La impronta de los testamentos bajomedievales: entre la precariedad de lo corporal y la durabilidad de lo espiritual», en Jaume Aurell y Julia Pavón (eds.), Ante la muerte, espacios y formas en la España medieval, Pamplona, Eunsa, 2002, págs. 77-93.

\footnotetext{
${ }^{21}$ El Cardenal, que Cervantes recuerda por su suma caridad en el Prólogo de la segunda parte del Quijote, era tío del Duque de Lerma y fue uno de los más ricos e influyentes protectores de las artes en la época de Felipe III. Véase Cavero de Carondelet (2016).
} 
"Porque tiene hambre canina, que nunca se harta". Narraciones de la muerte en Cervantes

Azpeitia Martín, María, «Historiografía de la "Historia de la Muerte"», Studia Historica. Historia Medieval, n. ${ }^{\circ}$ 26, 2008, págs. 113-132.

Bachtin Mijail, La cultura popular en la Edad Media y en el Renacimiento, versión de Julio Forcat y César Conroy, Madrid, Alianza Editorial, 2003.

Barco Cebrián, Lorena C., «Las voces de mujeres medievales a través de los testamentos y los inventarios: el caso de Leonor Pimentel y Zúñiga, I Duquesa de Plasencia», en Esther Corral Díaz (ed.), Voces de mujeres en la Edad Media: Entre realidad y ficción, Berlin/Boston, De Gruyter, 2018, págs. 124-134.

Bernabò, Barbara, Placidia Doria Spinola, una dama genovese tra Liguria, Lunigiana e Regno di Napoli, Pistoia, Associazione Culturale «Davide Beghé», 2002.

Cadaveira López, Paula, «Las mujeres y el encargo de peregrinaciones post-mortem en los testamentos bajomedievales de los reinos hispánicos», en Esther Corral Díaz (ed.), Voces de mujeres en la Edad Media: Entre realidad y ficción, Berlin/ Boston, De Gruyter, 2018, págs. 135-144.

Casey, James, «"Queriendo poner mi ánima en carrera de salvación”, la muerte en Granada (Siglos XVII-XVIII)», Cuadernos de Historia Moderna, Anejos, 2001, n. ${ }^{\circ} 1$, págs. 17-43.

Castro, Américo, Hacia Cervantes, Madrid, Taurus, 1957; Cervantes y los casticismos españoles, Madrid-Barcelona, Alfaguara, 1966.

Cavero de Carondelet, Cloe, Art, Piety and Conflict in Early Modern Spain: The Religious and Artistic Patronage of Cardinal Bernardo de Sandoval between Toledo and Rome (1599-1618), Thesis for PhD in History and Civilisation, Florence, 20 December 2016.

Cervantes, Miguel de, Obras dramáticas, ed. de Francisco Ynduráin, Madrid, Atlas, 1962.

Cervantes, Miguel de, Los trabajos de Persiles y Sigismunda, ed. de Juan Bautista Avalle-Arce, Madrid, Clásicos Castalia, 1990.

Cervantes, Miguel de, La Galatea, ed. de Francisco López Estrada y María Teresa López García-Berdoy, Madrid, Cátedra, 1995.

Cervantes, Miguel de, Novelas ejemplares I, II, ed. de Harry Sieber, Madrid, Cátedra, 2003.

Cervantes, Miguel de, Don Quijote de la Mancha, edición del IV Centenario, Madrid, Real Academia Española/Asociación de Academias de la Lengua Española, 2004.

Cervantes, Miguel de, La destruición de Numancia, Madrid, Clásicos Castalia, 2005.

Cervantes, Miguel de, Viaje del Parnaso y otras poesías, ed. de Laura Fernández García, Barcelona, Penguin Random House, 2016.

Chiffoleau, Jacques, La comptabilité de l'au-delà: Les hommes, la mort et la religion dans la région d'Avignon à la fin du Moyen Age (vers 1320 - vers 1480), préface de Jacques Le Goff, Roma, École Française de Rome, 1980. 
Coria Colino, Jesús, «El testamento como fuente de estudio sobre mentalidades (ss. XIII-XV)», Miscelánea Medieval Murciana, n. ㅇ 9, 1982, págs. 193-219.

Edmond Cros, «Reformuler la lecture que Bakhtine fait du Quichotte», Sociocriticism, IV, 1988, págs. 115-44.

Falcón Pérez, María Isabel y García Herrero, María del Carmen, «La muerte y los rituales funerarios según los testamentos bajomedievales aragoneses», en Francesco Salvestrini, Gian Maria Varanini y Anna Zangarini (eds.), La morte e $i$ suoi riti in Italia tra Medioevo e prima età moderna, Florencia, Firenze University Press, 2007, págs. 323-375.

Fernández Gonzalo, Jorge, «Elementos carnavalescos en El Quijote. Del carnaval al libro y del libro al carnaval», Etiópicas, n. ${ }^{\circ}$ 6, 2010, págs. 27-47.

Gambin, Felice, Azabache. El debate sobre la melancolía en la España de los Siglos de Oro, Madrid, Biblioteca Nueva, 2008.

García Fernández, Máximo, «"Don Quijote dio su espíritu, quiero decir que se murió”. Claves de la mentalidad tanática barroca castellana», Estudios Humanísticos, n. ${ }^{\circ}$ 7, 2008, págs. 161-200.

González Lopo, Domingo Luis, «El ritual de la muerte barroca: la hagiografía como paradigma del buen morir cristiano», Sémata. Ciencias Sociais e Humanidades, n. ${ }^{\circ} 17,2005$, págs. 299-320.

González Zymla, Herbert, «La danza macabra», Revista Digital de Iconografía Medieval, vol. VI, n. ${ }^{\circ} 11,2014$, págs. 23-51.

Gonzalo Sánchez-Molero, José Luis, «La “Epistola a Mateo Vázquez”, redescubierta y reivindicada», Cervantes: Bulletin of the Cervantes Society of America, vol. 27, n. ${ }^{\circ}$ 2, 2007, págs. 181-211.

Hutchinson, Steven, «Del anticlímax y sus virtudes en el Quijote de 1615 (la muerte parentética)», en Antonio Cortijo Ocaña, Gustavo Illades Aguiar, Francisco Ramírez Santacruz (eds.), El «Quijote» de 1615. Dobleces, inversiones, paradojas, desbordamientos e imposibles, Santa Barbara, University of California, Publications of eHumanista, 2016, págs. 120-131.

Iffland, James, «"El espantajo y el coco del mundo": la risible muerte de don Quijote», en Antonio Cortijo Ocaña, Gustavo Illades Aguiar, Francisco Ramírez Santacruz (eds.), El «Quijote» de 1615. Dobleces, inversiones, paradojas, desbordamientos eimposibles, Santa Barbara, University of California, Publications of eHumanista, 2016, págs. 132-144.

Iffland, James, «Don Francisco, don Miguel y don Quijote: un personaje en busca de testamento», Edad de Oro, n. ${ }^{\circ} 13,1994$, págs. 65-83.

Infantes, Víctor, Las Danzas de la Muerte. Génesis y desarrollo de un género medieval (siglos XIII-XVII), Salamanca, Ediciones Universidad de Salamanca, 1997. 
"Porque tiene hambre canina, que nunca se harta". Narraciones de la muerte en Cervantes

Le Goff, Jacques, La naissance du purgatoire, Paris, Gallimard, 1981.

Macías Rodríguez, Claudia, «Vestidos y disfraces en las transformaciones de Don Quijote», Espéculo. Revista de Estudios Literarios, n. ${ }^{\circ}$ 30, 2005.

Mitre Fernández, Emilio, «Muerte y modelos de muerte en la edad media clásica», Edad Media: Revista de Historia, n. ${ }^{\circ}$ 6, 2003-2004, págs. 11-31.

Molho, Mauricio, Cervantes: raices folklóricas, Madrid, Gredos, 1976.

Morreale, Margherita, «Dança general de la muerte (I)», Revista de Literatura Medieval, n. ${ }^{\circ} 3,1991$, págs. 9-50.

Morreale, Margherita, «La dança general de la muerte (II)», Revista de Literatura Medieval, VIII, 1996, págs. 111-177.

Niccoli, Ottavia, «Conclusioni», en Francesco Salvestrini, Gian Maria Varanini y Anna Zangarini (eds.), La morte e $i$ suoi riti in Italia tra Medioevo e prima età moderna, Florencia, Firenze University Press, 2007,págs. 473-482.

Panowsky, Erwin, Studi di iconologia. I temi umanistici nell'arte del Rinascimento, Turín, Einaudi, 1975.

Pavón Benito, Julia, «El testamento, un símbolo de la peregrinatio», Anuario de Estudios Medievales, n. ${ }^{\circ}$ 34, 1, 2004, págs. 31-50.

Peñalver Alhambra, Luis, «Palabra de fin. Muerte y escritura en el Quijote», Escritura e imagen, vol. 2, 2006, págs. 103-120.

Perugini, Carla, «Buscando mercedes. Nuevos datos sobre Cervantes y los italianos», Critica del testo. Cervantes e l'Italia, XX/3, 2017, a cura di María Luisa Cerrón Puga e Isabella Tomassetti, págs. 197-215.

Prosperi, Adriano, «Premessa» a «I vivi e i morti», Quaderni Storici, vol. 17, n. ${ }^{\circ} 50$ (2), agosto 1982, págs. 391-410.

Redondo, Augustin, Otra manera de leer el Quijote, Madrid, Castalia, 1997.

Ripa, Cesare, Iconologia, a cura di Sonia Maffei, Testo stabilito da Paolo Procaccioli, Turín, Einaudi, 2012.

Rutherford, John, «"Testamento de don Quijote" (1606-14?)», en N. Griffin, C. Griffin, E. Southworth y C. Thompson (eds.), The Spanish Ballad in the Golden Age. Essays for David Pattison, Londres, Tamesis, 2008, págs. 79-91.

Sáez, Adrián J., «De muerte y locura: tres acotaciones sobre el final del Quijote», en La locura en la literatura cervantina, Anuario de Estudios Cervantinos, n. ${ }^{\circ} 8$, 2012, págs. 105-122.

Sáez, Adrián J., «De Cervantes a Quevedo: testamento y muerte de don Quijote», $L a$ Perinola, n. ${ }^{\circ} 16,2012$, págs. 239-258.

Schmidt, Raquel, «La praxis y la parodia del discurso del ars moriendi en el Quijote de 1615», Anales Cervantinos, vol. XIII, 2010, págs. 117-130. 


\section{Carla Perugini}

Sliwa, Krzysztof, Documentos de Miguel de Cervantes Saavedra y de sus familiares, Texas, Texas A\&M University, 2005.

Tenenti, Alberto, «Ars moriendi. Quelques notes sur le problème de la mort à la fin du XVe siècle», Annales. Economies, sociétés, civilisations, $6^{\mathrm{e}}$ année, n. ${ }^{\circ}$ 4, 1951, págs. 433-446.

Vitale, Giuliana, «Pratiche funerarie nella Napoli aragonese», en Francesco Salvestrini, Gian Maria Varanini y Anna Zangarini, La morte e $i$ suoi riti in Italia tra Medioevo e prima età moderna, Florencia, Firenze University Press, 2007, págs. 377-440. 